\title{
Planeamento estratégico aplicado à carreira musical
}

\author{
Strategic plan applied to the musical career
}

Lucas Caldoncelli Gomes ${ }^{1}$; Leila Vaz da Silva ${ }^{2}$; Daniela Ferreira ${ }^{3}$.

${ }^{1}$ E-mail: lucascaldoncelli@gmail.com

Centro Universitário Metodista Izabela Hendrix

${ }^{2}$ E-mail: leila.silva@izabelahendrix.metodista.br Centro Universitário Metodista Izabela Hendrix

${ }^{3}$ E-mail: daniela.ferreira@izabelahendrix.metodista.br
Centro Universitário Metodista
Izabela Hendrix
Resumo: O presente artigo apresenta as principais etapas para o desenvolvimento de um planeamento estratégico para um empreendimento musical. Além das habilidades artísticas necessárias, a gestão estratégica apresenta-se como uma ferramenta fundamental para que se consiga alavancar uma carreira artística. Através desse documento foram definidas abordagens e conceitos necessários para se traçar os princípios norteadores (valores, missão e visão) e determinar os objetivos organizacionais. Além disso, realizou-se um trabalho exploratório dos ambientes que compõem o mercado musical na cidade de Belo Horizonte. A metodologia adotada para o estudo foi quanto aos fins exploratória, descritiva e aplicada. Quanto aos meios, tratou-se de um estudo de caso com abordagem quantitativa e qualitativa. $\mathrm{O}$ instrumento de coleta de dados deu-se por meio de entrevista com empreendedores do segmento musical e questionário estruturado aplicado via internet, para a pesquisa concorrencial. Após a etapa de coleta de dados, foi elaborado um plano estratégico, especificando os objetivos estratégicos globais desejados pelo artista, a fim de se elaborar um plano de ação a ser aplicado no desenvolvimento do empreendimento musical em questão.

Palavras-chave: Planeamento Estratégico; Empreendedorismo; Mercado da Música.

\begin{abstract}
This article presents the main steps of strategic planning for the development of musical enterprise. In addition to the necessary artistic skills, strategic management presents itself as a fundamental tool for the achievement of an artistic career. Through this document, the necessary approaches and concepts were defined to structure the guiding principles (values, mission and vision) and to determine the organizational objectives. Moreover, an exploratory work was carried out on the environments that make up the music market in the city of Belo Horizonte. The methodology used for the study was for exploratory, descriptive and applied purposes. As for the means, it was a case study with a quantitative and qualitative approach. The instrument of data collection was done through an interview with entrepreneurs of the musical segment and structured questionnaire applied through the internet, for competitive research. After the data collection stage, a strategic plan was drawn up, specifying the overall strategic objectives desired by the artist, in order to elaborate a plan of action to be applied in the development of the musical enterprise in question.
\end{abstract}

Keywords: Strategic planning; Entrepreneurship; Music Market. 


\section{Introdução}

A indústria musical, através dos seus três eixos principais: apresentações, fonogramas e direito autoral, faz parte da chamada economia criativa e abrange outros setores artísticos e culturais, bem como o setor de tecnologia da informação e da comunicação, e ainda os serviços de design, publicidade, moda e arquitetura (SALAZAR, 2015).

Neste contexto torna-se fundamental ao empreendedor musical diferenciar-se, devendo possuir uma série de conhecimentos teóricos, habilidades técnicas e atitudes, não só relacionadas às artes, mas também um profundo conhecimento na gestão empresarial, em marketing e na cultura empreendedora para impulsionar a sua carreira.

Novos consumidores musicais exigem a adoção de novos modelos de negócios, sobrevive somente aquele que se adapta melhor e mais rápido às mudanças do ambiente. Segundo Levesque (1999), as estratégias adotadas no passado possibilitaram a sobrevivência até ao momento, mas uma nova estratégia deve ser criada no sentido de se garantir a sobrevivência diante das mudanças no ambiente.

Diante dessas considerações, pergunta-se: é possível impulsionar carreiras musicais independentes por meio da cultura empreendedora e do planeamento estratégico? Quais estratégias podem impulsionar uma carreira musical independente na capital mineira?

O objetivo geral consiste em desenvolver um planeamento estratégico para um empreendimento musical (Lugera) a fim de se impulsionar uma carreira musical independente.

Os objetivos específicos são:

- Definir os princípios norteadores (valores, missão e visão) da banda Lugera;

- Analisar a concorrência por meio de entrevistas e questionários com o maior número possível de agentes musicais na cidade de Belo Horizonte;

- Desenvolver um planeamento estratégico para um empreendimento musical (Lugera), formulando os objetivos estratégicos; 


\section{pontěditora}

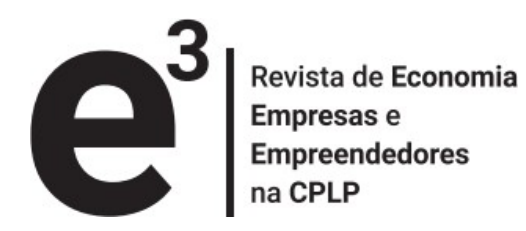

- Elaborar um plano de ação a ser aplicado no desenvolvimento do empreendimento musical.

Belo Horizonte possuí uma enorme população de artistas ligados à área musical. Infelizmente a grande maioria não atinge os seus objetivos, justamente, por não possuir um planeamento estratégico que vislumbre objetivos a longo prazo. Por meio da experiência do autor no ramo musical, pretende-se desenvolver o planeamento estratégico da sua banda, Lugera, de modo que essa ferramenta possibilite traçar e alcançar metas no médio e longo prazo, de forma a impulsionar a carreira musical.

A estratégia no ramo musical constitui uma das principais peças numa carreira de sucesso e, pela falta dele, muitos músicos, mesmo talentosos, não chegam aonde poderiam chegar e ficam estagnados em suas carreiras.

Portanto, um trabalho científico com o objetivo de pesquisar estratégias de gestão para propostas musicais apresentará ferramentas de grande valia no desenvolvimento de uma cena musical mais forte e consciente de suas capacidades, considerando que os gestores de trabalhos musicais muitas vezes são os próprios integrantes do grupo. Uma base de conhecimento bem estruturada apresenta um caminho para que se consiga alavancar os negócios.

O presente artigo científico também se justifica como critério imperioso para que o autor obtenha o título de Bacharel em administração do Curso de Administração do Centro Universitário Metodista Izabela Hendrix, e nesse sentido, o que se deseja é unir o útil ao agradável.

\section{Empreendedorismo}

Um primeiro exemplo de definição de empreendedorismo pode ser exemplificado com a tentativa de Marco Polo em estabelecer uma rota comercial para o Oriente. Na época, ele assinou um contrato para vender mercadorias de um capitalista. No caso, todos os riscos físicos e emocionais foram assumidos por Marco Polo. Durante a Idade Média, o empreendedor era aquele que gerenciava grandes projetos de produção, mas sem assumir riscos excessivos, uma vez que os recursos eram disponibilizados, geralmente, por governos. Somente no século XVII, surgem indícios de relação entre assumir riscos e empreendedorismo.

$\mathrm{e}^{3}$ - Revista de Economia, Empresas e Empreendedores na CPLP | Volume 4 | Número 1 


\section{pontěditora}

Neste período, os empreendedores faziam contratos com governos para a realização de serviços ou fornecimento de produtos. Richard Cantillon, importante escritor e economista do século XVII, foi um dos primeiros a diferenciar o empreendedor (aquele que assume riscos) do capitalista (aquele que fornecia capital) e, finalmente, no século no XVIII o capitalista e o empreendedor foram totalmente diferenciados, possivelmente devido à Revolução Industrial (DORNELAS, 2012).

Nos séculos XIX, XX e até os dias atuais, empreendedores são frequentemente confundidos com os gerentes ou administradores; a respeito desse assunto,

Todo empreendedor necessariamente deve ser um bom administrador para obter sucesso, no entanto, nem todo bom administrador é um empreendedor. $O$ empreendedor tem algo mais, algumas características e atitudes que o diferenciam do administrador tradicional (DORNELAS, 2012, p. 21)

Segundo o SEBRAE (2017), o futuro de uma empresa depende dos cuidados do seu dono. O perfil e o talento do futuro empresário são fundamentais para o sucesso do negócio. Um espírito criativo e pesquisador é uma das qualidades fundamentais de um empreendedor. A essência do empresário de sucesso é a busca de novos negócios e oportunidades, além da preocupação com as necessidades dos clientes e a melhoria dos produtos e serviços (DORNELAS, 2012).

Acredita-se, hoje, que o empreendedor seja o "motor da economia", um agente de mudanças. O empreendedor é alguém que sonha e busca transformar o seu sonho em realidade (DOLABELA, 1999).

O empreendedorismo, para Dornelas (2012), é a identificação de novas oportunidades e negócios, independentemente dos recursos que se apresentam disponíveis ao empreendedor, ou seja, identificar ideias inovadoras, procurando transformá-las em oportunidade, mesmo com poucos recursos. Um empreendedor de sucesso é aquele que busca o novo, planeia e organiza as suas ideias, procurando criar ou atender às necessidades das pessoas. Procura organizar os recursos disponíveis para atingir objetivos específicos.

Segundo Dornelas (2012), quando se compara o papel e função do empreendedor com o do administrador existem muitos pontos em comum entre ambos. O empreendedor é um administrador, mas diferentemente dos gerentes e executivos tradicionais, os empreendedores são mais visionários. Assim, à medida que a 


\section{pontěditora}

organização cresce, os empreendedores têm dificuldades com as decisões do negócio, pois concentram-se mais em aspetos estratégicos. Algumas orientações são básicas, a definição da estratégia, a análise de oportunidades, o comprometimento e o controlo dos recursos e a estrutura gerencial. Percebe-se diferenças no domínio de empreendedores e administradores.

Os empreendedores são orientados pela perceção de oportunidades e ação, utilizam o mínimo de recursos existentes, buscando eficiência, estão envolvidos numa estrutura gerencial informal com o relacionamento pessoal. Outros aspetos relevantes no comportamento empreendedor são a busca por independência, criando algo novo para ganhar dinheiro, envolvimento direto nos negócios, capacidade de assumir riscos calculados e aprendizado com erros e falhas. Assim Dornelas conclui:

O empreendedor de sucesso possui características extras, além dos atributos do administrador, e alguns atributos pessoais que, somados a características sociológicas e ambientais, permitem o nascimento de uma nova empresa. De uma ideia, surge uma inovação, e desta, uma empresa (DORNELAS, 2012, p. 23).

A respeito da relação do empreendedorismo com outras disciplinas, Baron e Shane explicam:

Fica claro que o campo do empreendedorismo não existe em um vácuo intelectual; pelo contrário, suas raizes estão firmemente assentadas em várias disciplinas mais antigas que, juntas, lhe dão sustentação para compreender um dos mais complexos - e importantes - processos de negócio que existe (BARON; SHANE, 2007, p. 11).

Conclui-se que a ciência da Administração torna-se de grande importância aos empreendedores, pois ajuda-os a adquirir competências e habilidades complementares ao seu conhecimento, preparando-os para as mais diferentes tarefas envolvidas no processo de criação e gerência de novos negócios.

\subsection{Planeamento Estratégico: abordagens e conceitos}

Em tempos de mudanças e transformações que ocorrem de forma rápida e inesperada, a estratégia passa a ser uma direção salvadora nas organizações, capaz de levá-las aos seus objetivos mesmo com toda a instabilidade. Quanto maior a mudança

$\mathrm{e}^{3}$ - Revista de Economia, Empresas e Empreendedores na CPLP | Volume 4 | Número 1 


\section{pontěditora}

maior a necessidade de estratégia organizacional. $\mathrm{O}$ detalhe consiste na necessidade, na atualidade das estratégias apresentarem-se ágeis, rápidas, flexíveis e inovadoras, permitindo melhor o enfrentamento das turbulências presentes no ambiente competitivo (CHIAVENATO; MATOS, 2009).

O estudo da administração estratégica foi primeiramente adotado nas escolas de administração americanas, nos anos 50, após a Fundação Ford e a Carnegie Corporation patrocinarem uma pesquisa sobre currículos. Um resumo desta pesquisa recomendou que o ensino de administração passasse a incluir um curso de capacitação em política de negócios. O enfoque de tal curso seria a identificação, análise e a solução de problemas do mundo real em várias áreas. Isso permitiria aos estudantes realizar julgamentos. Com o tempo, tal enfoque ampliou-se para incluir a organização global e o seu ambiente, tornando a responsabilidade social e a ética, assim como o impacto de factores políticos, legislativos e económicos, assuntos primordiais no êxito das operações de uma organização (CERTO; PETER, 2005).

Mintzberg (2006) divide a estratégia em cinco definições:

1 - Estratégia como plano: a estratégia significa um plano unificado amplo e integrado, criado para assegurar que os objetivos básicos da empresa sejam atingidos. Planos necessariamente criados antes das ações, as quais vão aplicar-se, e desenvolvidos consciente e propositalmente;

2 - Estratégia como padrão: definir uma estratégia como plano não seria suficiente, necessário se faz uma definição que englobe o comportamento resultante. Portanto, estratégia representa a consistência no comportamento, pretendida ou não;

3 - Estratégia sobre o que: rotular estratégias como planos ou padrões levantam a questão básica: estratégias sobre o quê? Estratégias referem-se a coisas importantes, táticas são os detalhes. Mas alguns detalhes podem ser estratégicos. Portanto, o que é estratégico depende do ambiente. Não se deve usar rótulos para indicar que questões são inevitavelmente mais importantes que outras. A estratégia refere-se, potencialmente, a tudo;

4 - Estratégia como posição: um meio de localizar uma organização num ambiente. A estratégia torna-se uma força, ou a combinação entre organização e ambiente, ou seja, entre o ambiente interno e externo. Num contexto de vários 


\section{pontěditora}

competidores a estratégia torna-se um nicho, ou seja, um local no ambiente onde os recursos concentram-se;

5 - Estratégia como perspetiva: nesse aspeto a estratégia constitui para a organização aquilo que a personalidade significa para o indivíduo. Não significando apenas uma posição escolhida, mas também uma maneira fixa de olhar o mundo. Neste contexto, estratégia envolve uma perspetiva compartilhada pelos membros de uma organização, por suas intenções e/ ou por suas ações.

Assim, a estratégia não é apenas a noção de como lidar com um grupo de concorrentes, ela também nos leva a algumas questões mais fundamentais sobre as organizações como instrumentos para percepção e ação coletiva. (MINTZBERG, 2006, p. 29)

Segundo Certo e Peter (2005, p. 3), “a administração estratégica é definida como um processo contínuo e interativo que visa manter uma organização como um conjunto apropriadamente integrado a seu ambiente". Percebe-se nesse conceito a natureza de longo prazo do planeamento estratégico devido a seu caráter contínuo. Assim, a necessidade de adaptar as estratégias de acordo com as condições do ambiente apresentado.

Chiavenato e Matos $(2009$, p. 1) acrescentam que "a visão estratégica é antecipatória e proativa. Antever e não agir estrategicamente é realizar a profecia do caos, como um feiticeiro que acaba mergulhando no caldeirão fervente para provar suas teorias". Portanto, as organizações que se planeiam estão operando estrategicamente contra os movimentos que venham a ameaçar seu funcionamento, devido a mudanças no ambiente, e as que não planeiam, ou que planeiam, mas não agem, estão contribuindo para a própria destruição.

Certo e Peter (2005) resumem o planeamento estratégico como:

Um processo contínuo e interativo voltado para a manutenção da organização como um todo integrado de forma apropriada a seu ambiente. Esse processo envolve análise do ambiente, estabelecendo diretrizes organizacionais, formulações da estratégia, implementação da estratégia e controle estratégico. Também é importante que as principais funções de negócio dentro de uma organização - marketing, operações e finanças - estejam integradas com o processo de administração estratégica. (CERTO; PETER, 2005, p. 17)

$\mathrm{e}^{3}$ - Revista de Economia, Empresas e Empreendedores na CPLP | Volume 4 | Número 1 


\section{pontěditora}

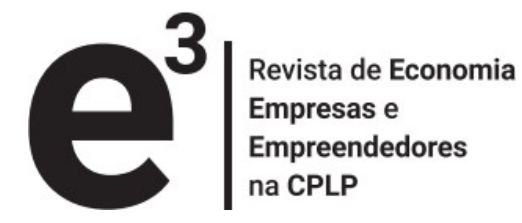

Ainda de acordo com Certo e Peter (2005, p. 13), “o administrador estratégico bem-sucedido deve ser capaz de analisar as principais funções de negócio dentro da organização e entender como elas afetam o processo de administração estratégica e de que maneira devem ser integradas a ele". Assim sendo, destaca-se a importância de uma análise profunda das funções do negócio dentro de uma organização. Como ponto de partida de um planeamento estratégico, torna-se necessário um planeamento financeiro da empresa, criando-se um sistema ajustado com a quantidade de recursos disponíveis. Depois, deve-se planear o futuro, deixando de trabalhar somente com aquilo que se tem em mãos e projetar quais são as ambições futuras da organização, e como o marketing, as operações e o bom gerenciamento dos recursos materiais e financeiros podem auxiliar na realização de tais planos (ROCHA, 2012).

Complementando, Chiavenato e Matos (2009) conceituam o planeamento estratégico como:

Um processo organizacional compreensivo de adaptação organizacional pela aprovação, tomada de decisão e avaliação. Procura responder a algumas questões básicas, como: por que a organização existe, o que e como ela faz. O resultado do processo é um conjunto de planos altamente integrado e flexivel que serve para guiar a ação organizacional por um prazo de tempo pela frente (CHIAVENATO; MATOS, 2009, p. 36)

Segundo os autores, o planeamento estratégico apresenta cinco características fundamentais:

1 - Relaciona-se com a adaptação da organização a um ambiente mutável. Foca nas relações entre a organização e o seu ambiente de tarefa, muito sujeito a incerteza a respeito dos eventos ambientais que se sucedem numa ampla variedade de cursos de ação;

2 - Orientado para o futuro, para tanto depende da construção de cenários e de desdobramentos esperados da situação atual;

3 - Envolve toda a organização, utilizando todos os seus recursos e competências, no sentido de obter sinergia de suas capacidades e potencialidades. A resposta estratégica da organização envolve um comportamento global, compreensivo, holístico e sistémico. O planeamento estratégico deve ficar na cabeça e no coração das pessoas. Elas precisam conhecer os objetivos a alcançar de maneira consciente, compromissada e engajada;

$\mathrm{e}^{3}$ - Revista de Economia, Empresas e Empreendedores na CPLP | Volume 4 | Número 1 


\section{pontěditora}

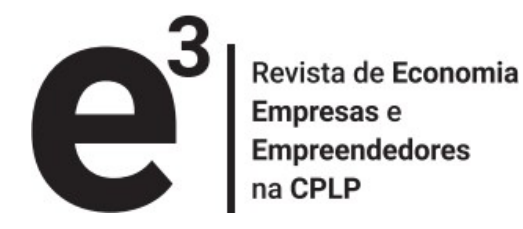

4 - Processo de construção de consenso, dada a diversidade dos interesses e necessidades dos parceiros que contribuem para que a organização possa alcançar os seus objetivos. Aceitação ampla e incondicional para que o planeamento estratégico possa ser realizado pelas pessoas em todos os níveis organizacionais;

5 - Forma de aprendizagem organizacional já que constitui uma tentativa permanente em aprender a ajustar-se a um ambiente complexo, dinâmico, competitivo e mutável. Os ajustes internos apresentam sempre novos estilos de aprender a conviver em conjunto e cooperar para que a união faça a força da organização.

\subsection{Processo de administração estratégica}

Certo e Peter (2005) dividem o processo da administração estratégica em 5 etapas distintas a seguir:

Etapa 1 - Análise do ambiente: consiste num processo de monitoração do ambiente organizacional, também conhecido como análise SWOT. Entende-se ambiente organizacional como sendo todos os factores, internos e externos, que podem influenciar o progresso alcançado por meio da realização dos objetivos.

Analisar o ambiente de negócio consiste em identificar os principais factores que influenciam direta ou indiretamente um empreendimento. Factores económicos, socioculturais, demográficos, político-legais, tecnológicos e naturais precisam ser mapeados, pois podem provocar impacto ao negócio. Além disso, o empreendedor precisa conhecer mais detalhadamente o setor que pretende atuar.

De acordo com Kotler e Keller (2006), as empresas bem-sucedidas reconhecem as necessidades e as tendências não atendidas e tomam medidas para lucrar com elas. Segundo os autores, para ajudar as organizações a identificar mudanças culturais, que possam trazer novas oportunidades ou ameaças, várias empresas oferecem previsões socioculturais.

Ainda segundo Kotler e Keller (2006), a principal força a ser monitorada é a população. Afinal, os mercados são compostos por pessoas. Aspetos como o tamanho e a taxa de crescimento da população de diferentes regiões, composição etária e étnica da população, graus de instrução, padrões familiares, são de fundamental importância para a compreensão das tendências demográficas e como tais factores podem influenciar os negócios. 


\section{pontěditora}

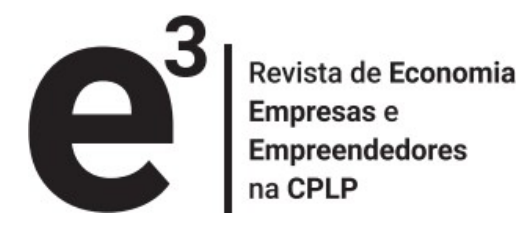

As mudanças no ambiente político-legal possuem uma força muito grande e afetam as decisões. Esse ambiente é constituído por leis e órgãos governamentais que influenciam, regem e limitam várias organizações e pessoas. Algumas vezes, essas leis geram novas oportunidades de negócios, por exemplo Leis de Incentivo à Cultura. As duas principais tendências no ambiente político-legal são: o aumento da legislação que regulamenta os negócios e o crescimento dos grupos de interesses especiais (KOTLER e KELLER, 2006).

Na visão de Chiavenato (2003), as condições legais formam a legislação que está em vigor que afeta direta ou indiretamente as empresas, auxiliando-as ou impondo restrições às suas atividades organizacionais, como exemplo as leis comerciais, trabalhistas, fiscais e civis. As condições políticas correspondem às decisões que influenciam as organizações e orientam as condições económicas. O ambiente políticolegal é primordial, visto que afeta diretamente a sociedade e as organizações, devido às mudanças políticas e ao surgimento de leis que são aprovadas ou modificadas que podem afetar diretamente as ações das organizações (KOTLER e KELLER, 2006). Em vista disso, as organizações devem analisar de forma criteriosa as considerações político legais ao definir suas estratégias de negócios.

De acordo com Kotler e Armstrong (1998), para ser bem sucedida, uma empresa deve satisfazer necessidades e desejos dos consumidores melhor do que os seus concorrentes. O desenvolvimento que ocorre nas outras organizações provoca profundas influências nas organizações, principalmente quando se trata de tecnologia sujeita a inovações, ou seja, tecnologia dinâmica de futuro imprevisível. As organizações precisam adaptar-se e incorporar tecnologia que provém do ambiente geral para não perderem a sua competitividade.

Etapa 2 - Estabelecimento das diretrizes organizacionais: determinação dos princípios norteadores da organização. Os indicadores principais da direção para a qual leva-se a organização são os valores, a missão e a visão. Valores "são os balizamentos para o processo decisório e o comportamento da empresa no cumprimento da sua missão" (VASCONCELOS; PAGNONCELLI, 2001, p. 31); Missão "é a razão de existir da empresa no seu negócio" (VASCONCELOS; PAGNONCELLI, 2001, p. 31); e Visão "é a explicitação do que se visualiza para a empresa" (VASCONCELOS; PAGNONCELLI, 2001, p. 31). 


\section{pontěditora}

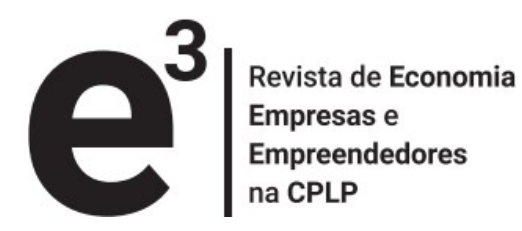

Etapa 3 - Formulação da estratégia: define-se a estratégia como um curso de ação para garantir que se alcance os objetivos.

Etapa 4 - Implementação da estratégia: deve pôr em ação estratégias que surgiram de etapas anteriores dentro do processo de administração estratégica. Sem implementação efetiva da estratégia as organizações são incapazes de obter os benefícios da realização de uma análise organizacional, do estabelecimento de uma diretriz organizacional e da formulação da estratégia organizacional.

Etapa 5 - Controlo estratégico: representa um tipo característico de controlo organizacional que se aplica no monitoramento e na avaliação do processo de administração estratégica para melhorá-lo e assegurar-lhe um funcionamento apropriado.

Portanto, trata-se de um conjunto de compromissos, decisões e ações imperiosas às empresas realmente interessadas em obter vantagens competitivas e retornos acima da média.

Ao analisar adequadamente o ambiente interno e externo determina-se os recursos, capacitações, e competências essenciais, os chamados inputs ou fontes de informações estratégicas. Com as informações, o negócio desenvolve a sua visão e missão e formula a sua estratégia. Para implementar uma estratégia tomam-se ações, a fim de obter vantagem competitiva e retornos acima da média. Ações estratégicas eficazes são as que ocorrem de maneira integrada entre as etapas de formulação e implementação da estratégia e, portanto, produzem os resultados desejados. O processo torna-se dinâmico, visto que os mercados mudam constantemente e a gestão de tais estruturas, por meio das informações estratégicas pertinentes, está em constante evolução (HITT; IRELAND; HOSKISSON, 2008).

Complementando, de acordo com Hamel e Prahalad (1995), considera-se o planeamento estratégico também como um meio de competição pela previsão do futuro do setor, proporcionando aos gestores respostas a três questões fundamentais: Que novos tipos de benefícios poderemos oferecer aos clientes? Que novas competências precisaremos desenvolver ou adquirir para oferecer esses benefícios aos clientes? Como será o contacto? 


\section{pontěditora}

Segundo Hamel e Prahalad (1995, p. 83), "a meta de competição pela previsão do futuro do setor é criar a melhor base de premissas possível sobre o futuro e, assim, desenvolver a presciência necessária para moldar a evolução do setor".

\subsection{Importância do planeamento estratégico para o empreendedor musical}

O mercado musical nunca mais foi o mesmo desde 2002, quando um programa de compartilhamento chamado Napster abriu a possibilidade de que os consumidores de música pudessem trocar arquivos em formato MP3 entre si de forma gratuita, segura e rápida. Embora o Napster original tenha fechado, os downloads gratuitos online continuam e as implicações disso até hoje interferem no mercado musical (KUSEK; LEONHARD, 2005).

A tecnologia, com o avanço da gravação digital, também possibilitou aos interessados adquirir equipamentos específicos de gravação, a preços acessíveis, permitindo que artistas não mais dependessem de estúdios para registrar seu trabalho. A partir daí a pessoa do músico independente passou cada vez mais a assumir todas as responsabilidades inerentes a uma carreira musical, atuando não só como artista, mas também como gestor.

O desenvolvimento da produção musical independente no país é marcado tanto por uma crise generalizada da indústria quanto por uma inédita organização da cena independente. Essa crise, que se vincula ao contexto geral da economia e a fatores específicos da indústria (como a pirataria digital e de formatos), parece estar afetando a capacidade das grandes gravadoras de atuar nos múltiplos segmentos do mercado, ampliando assim os espaços para a produção independente. (VICENTE, 2014, p. 2)

De acordo com Maurício Bussab (LA OTRA, 2017), diretor da Tratore, maior distribuidora de música independente no Brasil, a maior mudança começou quando os formatos de arquivo mudaram: com a possibilidade de baixar músicas gratuitamente, quem foi mais afetado, no geral, foram as gravadoras. No entanto, nos últimos anos, as formas de se consumir música e a forma de se investir no artista mudou. Hoje, as pessoas não querem ficar baixando conteúdo, elas consomem via streaming em plataformas como o Spotify ou o YouTube, e houve uma volta no interesse pela produção musical, tendo em vista que o fonograma tornou-se rentável novamente. Pela primeira vez na história, o negócio digital de música representa 50\% do negócio das 


\section{pontěditora}

gravadoras e, após muitos anos de prejuízo em 2016, de acordo com a Federação Internacional da Indústria Fonográfica (IFPI), o mercado fonográfico teve um relevante crescimento (IFPI, 2016).

Segundo Salazar (2015, p. 181), “a direção estratégica de uma carreira artística é uma forma de direcionamento focado no futuro, atento às mudanças, a fim de manter o artista no mercado globalizado. É andar com os pés no chão, mas com a cabeça olhando para frente".

Portanto, o planeamento estratégico de uma carreira musical inicia-se com a análise SWOT (ou FOFA) e procura identificar as forças que atuam sobre o ambiente interno e externo desta carreira. Pontos fracos ou negativos são forças de natureza interna que prejudicam o rendimento e favorecem o rendimento. Ameaças são forças externas e, portanto, fora do controlo do artista, que podem prejudicar o seu desempenho. Oportunidades são situações externas que podem beneficiar a sua carreira. Essa análise ajuda a resumir os principais factos e as previsões que se encontram após as análises externa e interna. A partir disso, pode-se extrair uma série de declarações que identificam as questões estratégicas com que a organização se depara (SALAZAR, 2015).

Após essa análise ambiental pode-se elaborar planos estratégicos táticos e operacionais pertinentes ao negócio pretendido. Considera-se o plano estratégico como o resultado global desejado pelo artista. A sua execução fundamenta-se no longo prazo e evidenciam as operações necessárias para alcançar o resultado global. O plano tático define objetivos que ajudam o artista a cumprir a sua missão e concretizar a sua visão. Os objetivos devem ser específicos, desafiadores e determinados. O plano operacional tem por finalidade estabelecer metas que sirvam para estipular pontos de controlo, aferir resultados parciais em curto prazo e indicar os responsáveis.

$\mathrm{O}$ controlo do planeamento engloba uma atividade rotineira que, por meio de informações repassadas pelos membros da banda, ou público ou qualquer agente pertinente, possibilita tomar decisões sobre o real desempenho em comparação com o objetivo, os riscos detetados, o que ainda falta fazer e qual a necessidade de alterar o objetivo.

Por exemplo, se o número de shows está abaixo do esperado, pode ser um erro de estratégia. Também deve-se avaliar as impressões do público, o que eles acham sobre 


\section{pontěditora}

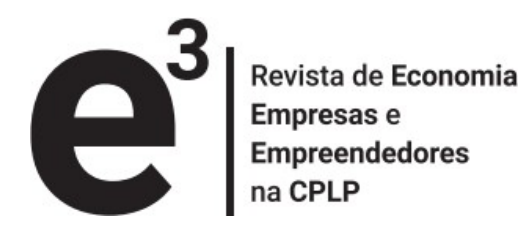

a qualidade do show. Outros agentes importantes são os músicos, técnicos, produtores e outros profissionais envolvidos no mercado. Muitas vezes eles observam outros ângulos de uma mesma situação. A comunicação, portanto, torna-se crucial nesta fase do planeamento estratégico (SALAZAR, 2015).

Concluindo, a indústria da música não é mais a mesma de há vinte anos atrás, até mesmo cinco anos atrás. Atualmente, artistas dirigem as suas carreiras da mesma forma que um empreendedor dirige uma startup, tudo isso sem ajuda de grandes corporações ou grandes gravadoras. A nova indústria da música gira em torno do faça você mesmo. Você escreve as músicas, grava e distribui para os fãs. Você mesmo é responsável por planear uma tournée, gerenciar e contactar seu público-alvo, criar sua estratégia de marketing. Tudo isso abre um amplo campo de oportunidades. Qualquer um pode se tornar bem-sucedido desde que possua as habilidades artísticas, a dedicação e a perseverança necessárias.

O modelo económico que norteou o negócio da música durante anos não é mais relevante. As gravadoras investiam pesadamente no desenvolvimento de carreiras, marketing e distribuição, assumindo os riscos. Um hit poderia justificar o investimento e permitir o desenvolvimento de outros artistas. Não é mais o caso. As gravadoras simplesmente não conseguem cobrir suas despesas com esse modelo. É preciso considerar os novos fluxos de receitas que podem ser gerados e trabalhar em um esforço coordenado para promovê-las. Criar a própria realidade é o jogo. A criatividade é um diferencial no momento de se definir um modelo económico e como ganhar dinheiro. A indústria em constante mutação está pronta para inovações, portanto, pensemos fora da caixa (KUSEK'S, 2014).

\section{Metodologia}

Entende-se como metodologia os procedimentos a serem seguidos na realização da pesquisa. Sua organização varia de acordo com as peculiaridades de cada pesquisa. Requer-se, no entanto, a apresentação de informações acerca de alguns aspectos (GIL, 2008).

De acordo com o proposto por Vergara (2007), o presente estudo teve o objetivo de desenvolver o Planeamento Estratégico para um empreendimento musical considerando-se os seguintes aspetos: quanto aos fins e quanto aos meios.

$\mathrm{e}^{3}$ - Revista de Economia, Empresas e Empreendedores na CPLP | Volume 4 | Número 1 


\section{pontěditora}

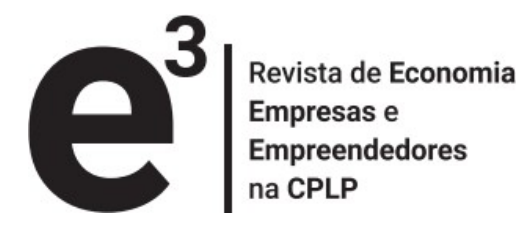

Quanto aos fins, trata-se de uma pesquisa exploratória, descritiva e aplicada. As pesquisas exploratórias têm como objetivo proporcionar maior conhecimento sobre um problema, no intuito de torná-lo mais explícito ou a elaborar hipóteses. O principal objetivo de tais pesquisas, portanto, consiste no aprimoramento de ideias ou a descoberta de intuições. Seu planeamento torna-se bastante flexível, de modo que permita a consideração dos mais variados aspetos relativos ao facto estudado. $\mathrm{Na}$ maioria dos casos, envolvem levantamento bibliográfico e entrevistas com pessoas que tiveram experiências práticas com o problema pesquisado e análise de exemplos pertinentes (GIL, 2008).

Dessa forma, o presente trabalho utilizou a pesquisa exploratória, pois tem como objetivo explorar e adquirir maior conhecimento sobre o mercado da música em Belo Horizonte, por meio de análise dos ambientes internos e externos de tal mercado, com o objetivo de propor soluções estratégicas para um empreendimento musical. Também se utilizou a pesquisa descritiva, por meio de uma entrevista, buscando-se observar fenómenos e entender os comportamentos, desejos, interesses e necessidades do mercado alvo.

\footnotetext{
As pesquisas descritivas têm como objetivo primordial a descrição das características de determinada população ou fenômeno ou, então, o estabelecimento de relações entre variáveis. São inúmeros os estudos que podem ser classificados sob este título e uma de suas características mais significativas está na utilização de técnicas padronizadas de coleta de dados, tais como questionário e a observação sistemática. (GIL, 2008, p. 42)
}

Segundo Vergara (2007), esta pesquisa caracteriza-se, por ser aplicada, já que foi criada a partir da necessidade de resolver problemas concretos em decorrência da falta de um Planeamento Estratégico.

Quanto aos meios, a pesquisa foi viabilizada por meio de estudo de caso, que Vergara (2007, p. 44) assim conceitua: "é o circunscrito a uma ou poucas unidades, entendidas essas como pessoa, família, produto, empresa, órgão público, comunidade ou mesmo país e tem caráter de profundidade e detalhamento".

De acordo com Gil (2008), os levantamentos abrangem um universo muito grande e, portanto, impossível de ser considerado em sua totalidade. Por essa razão, frequentemente se trabalha com amostras, ou seja, uma pequena parte do universo. Nos 


\section{pontěditora}

casos de a amostra ser rigorosamente selecionada, os resultados obtidos no levantamento tendem a aproximar-se bastante da realidade do universo.

O universo, no caso dessa pesquisa, foi restringido à empresa musical objeto do estudo, a banda Lugera. A amostra será censitária, tendo em vista que adotará a entrevista com um dos empreendedores da empresa. Para a pesquisa que embasou a análise da concorrência, optou-se por adotar amostra não probabilística, intencional, constituída exclusivamente de pessoas relacionadas ao ramo musical, preferencialmente músicos que possuam bandas com trabalho autoral. Como amostra foram selecionadas duas pessoas para a entrevista estruturada e cinquenta questionários respondidos via internet, voltados à análise concorrencial.

Para a pesquisa descritiva foi utilizada uma entrevista estruturada, em que o pesquisador seguiu um roteiro previamente estabelecido. Tal pesquisa permitiu que as repostas fossem comparadas com o mesmo conjunto de perguntas, refletindo as diferenças entre os entrevistados em relação ao assunto (MARCONI; LAKATOS, 2017).

Para a pesquisa exploratória foi utilizado um questionário, constituído por uma série ordenada de perguntas, que foram respondidas via internet, sem a presença do entrevistador.

O processo de análise de dados, tendo em vista a adoção de abordagem qualitativa e quantitativa, envolveu diversos processos: codificação das respostas, análise do conteúdo da entrevista, tabulação dos dados e cálculos estatísticos. Também envolveu a interpretação dos dados, que consiste em estabelecer a ligação entre os resultados obtidos com outros já conhecidos, e a partir desse ponto, ser capaz de desenvolver hipóteses acerca do assunto estudado (GIL, 2008).

Portanto, as análises dos dados provenientes das entrevistas foram interpretadas a fim de estabelecer conexões com o assunto do planeamento estratégico, por meio de uma análise qualitativa.

Os dados provenientes dos questionários foram codificados, tabulados e apresentados estatisticamente, por meio de gráficos e tabelas específicas para este fim.

Após análise dos dados, foram elaboradas as conclusões e propostas que abrangem o planeamento estratégico e um plano de ação para a empresa estudada.

$\mathrm{e}^{3}$ - Revista de Economia, Empresas e Empreendedores na CPLP | Volume 4 | Número 1 


\section{pontěditora}

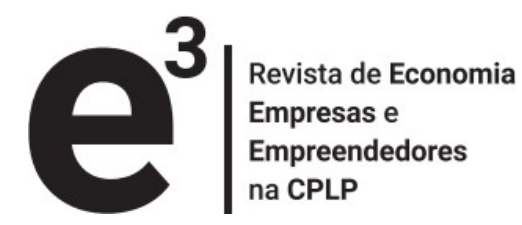

\section{Resultados e discussão}

A pesquisa deu-se por meio de um questionário voltado para análise da concorrência, no sentido de identificar a existência ou não de planeamento para a alavancagem da carreira musical, respondido por 49 pessoas, em sua maioria do sexo masculino, todas ligadas ao mercado musical independente de Belo Horizonte. Objetivando o aprofundamento para uma melhor elucidação do tema, foram realizadas entrevistas pessoais com três empreendedores da música, todos de Belo Horizonte, sendo um deles integrante da banda Lugera. As pesquisas foram realizadas durante os meses de julho e agosto de 2017. A seguir serão apresentados os resultados das duas pesquisas realizadas.

\subsection{Resultados da pesquisa}

As primeiras perguntas destinadas a compreender a realidade dos pesquisados foram relacionadas com a geração de renda com atividades musicais. A primeira pergunta buscou identificar a renda gerada com sua atividade musical e, caso positivo, qual seria esse valor. Os resultados seguem apresentados no Gráfico 1.

Gráfico 1 - Recursos financeiros gerados com a música

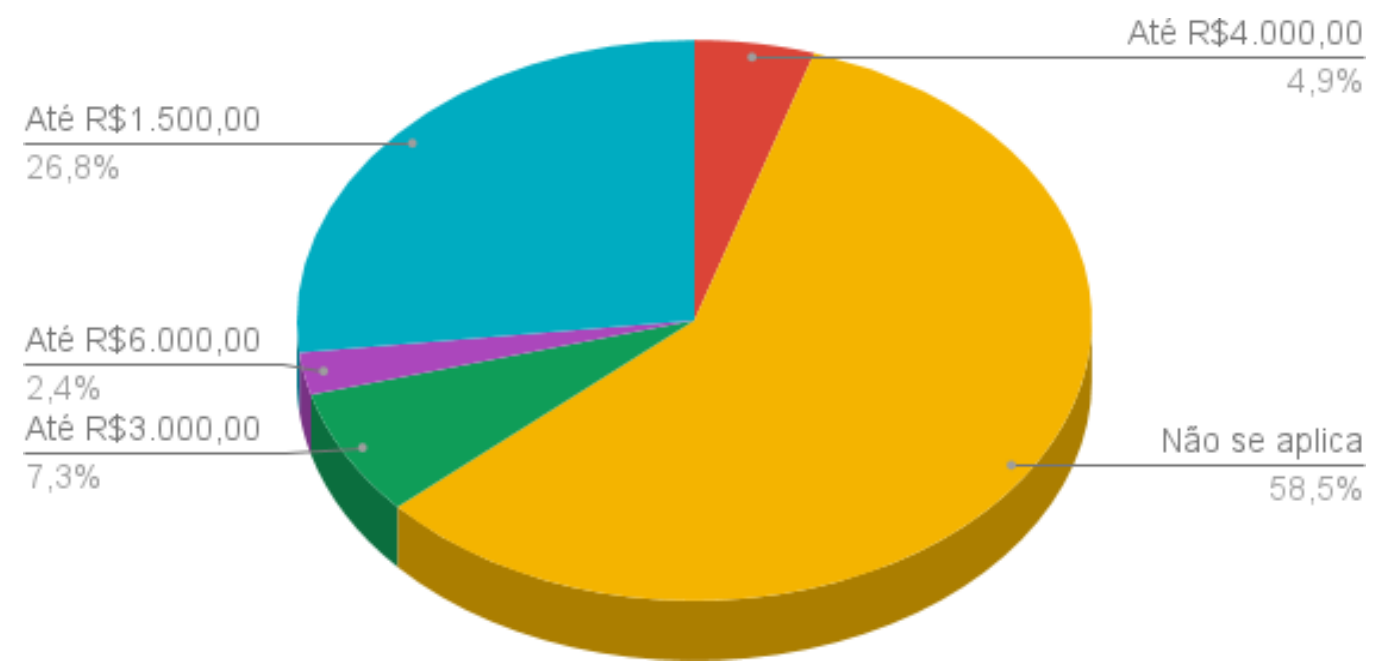

Fonte: Dados da pesquisa (2017)

$\mathrm{e}^{3}$ - Revista de Economia, Empresas e Empreendedores na CPLP | Volume 4 | Número 1 


\section{pontěditora}

Constatou-se que um pouco mais da metade $(58,5 \%)$ dos pesquisados não geram nenhum recurso financeiro com sua atividade musical. Dos $41,5 \%$ restantes que afirmaram obter renda por meio da atividade musical, 26,8\% conseguem atingir uma renda mensal de no máximo $\mathrm{R} \$ 1.500,00$, sendo esse percentual gradativamente diminuído à medida em que a faixa de renda aumenta. Pode-se concluir, pela análise desses dados, que a música não representa um trabalho rentável para a maioria daqueles que atuam nesse mercado e que apenas uma pequena parcela dos profissionais atinge um nível de renda razoável. Dentro de vários factores como o talento, capacidade técnica e nível de comprometimento, o sucesso financeiro provavelmente envolve um planeamento prévio, realizado de forma criteriosa de maneira a potencializar os pontos fortes identificados na análise do ambiente.

O Gráfico 2 buscou avaliar o grau de satisfação dos empreendedores da música em relação ao seu trabalho.

Gráfico 2 - Grau de satisfação com o próprio trabalho

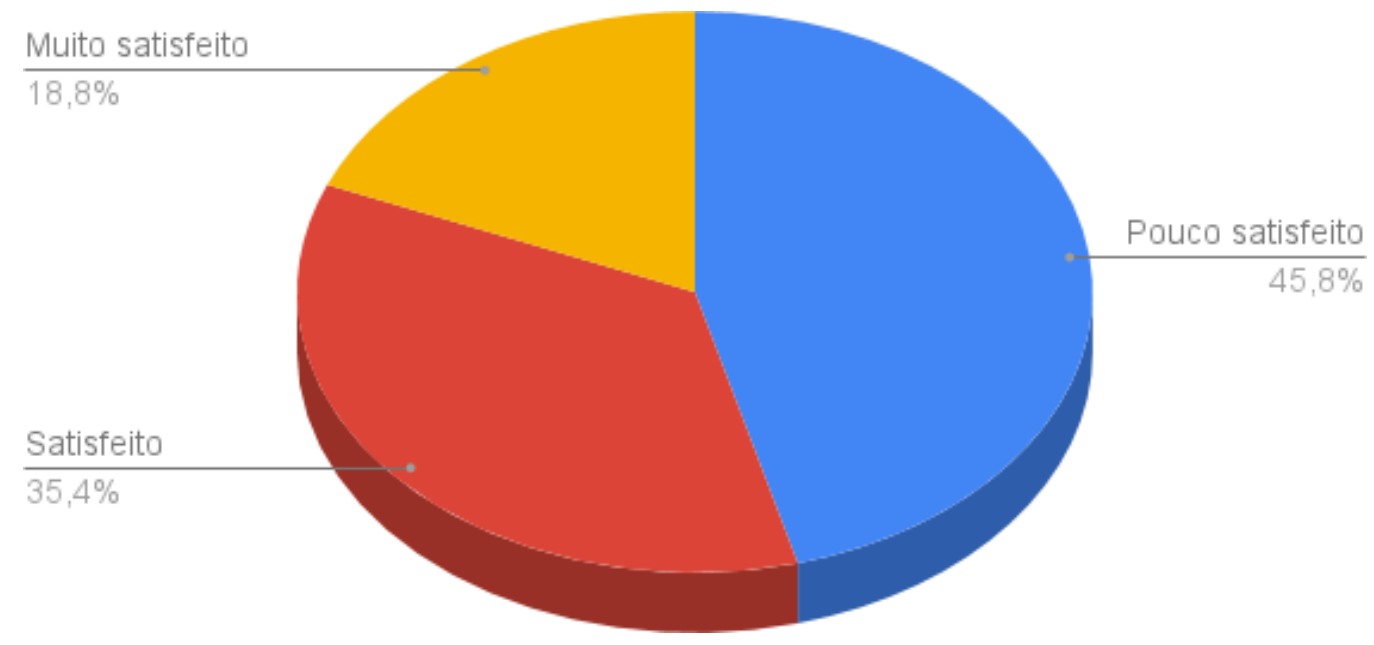

Fonte: Dados da pesquisa (2017) 


\section{pontěditora}

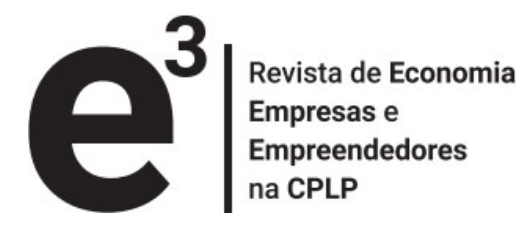

O resultado apresentado no Gráfico 2 chamou à atenção por constatar que quase metade da amostra pesquisada $(45,8 \%)$ está pouco satisfeita. Um dos motivos dessa insatisfação pode estar relacionado à falta de retorno financeiro constatada anteriormente, e uma consequente desilusão com o mercado musical. Essa condição pode estar associada ao entendimento de Vicente (2014) que sugere que o aumento da produção musical independente no país é marcado por duas situações distintas: primeiro, pela crise generalizada da indústria e, segundo, por uma incomum organização da cena independente. Ainda, de acordo com Dolabela (1999), alguns dos profissionais do ramo podem não apresentar como característica serem trabalhadores incansáveis, que realmente gostam do que fazem, trabalhando dia e noite, mas sempre com a consciência da qualidade que deve impor às suas tarefas, visando resultados e não ao trabalho em si. O resultado pode representar que uma grande parcela dos artistas não considera a música como um empreendimento, mas simplesmente uma atividade de entretenimento sem compromisso e que, portanto, não buscam posicionar-se estrategicamente de maneira a aproveitar as oportunidades oferecidas pelo aumento da produção musical e pela maior organização da cena independente, objetivando atingirem resultados melhores.

A próxima série de perguntas pretendeu analisar a atitude dos empreendedores musicais perante o mercado externo. O Gráfico 3 apresenta o comparecimento aos shows de outras bandas (concorrentes) e o Gráfico 4 apresenta a presença nos diversos eventos, seminários e encontros relacionados ao mercado da música, todos bons locais para se adquirir uma visão ou perceção sobre as tendências do setor, possibilitando a elaboração de estratégias baseadas em previsões sobre o futuro do mesmo. 
Gráfico 3 - Frequência em shows de outras bandas/artistas

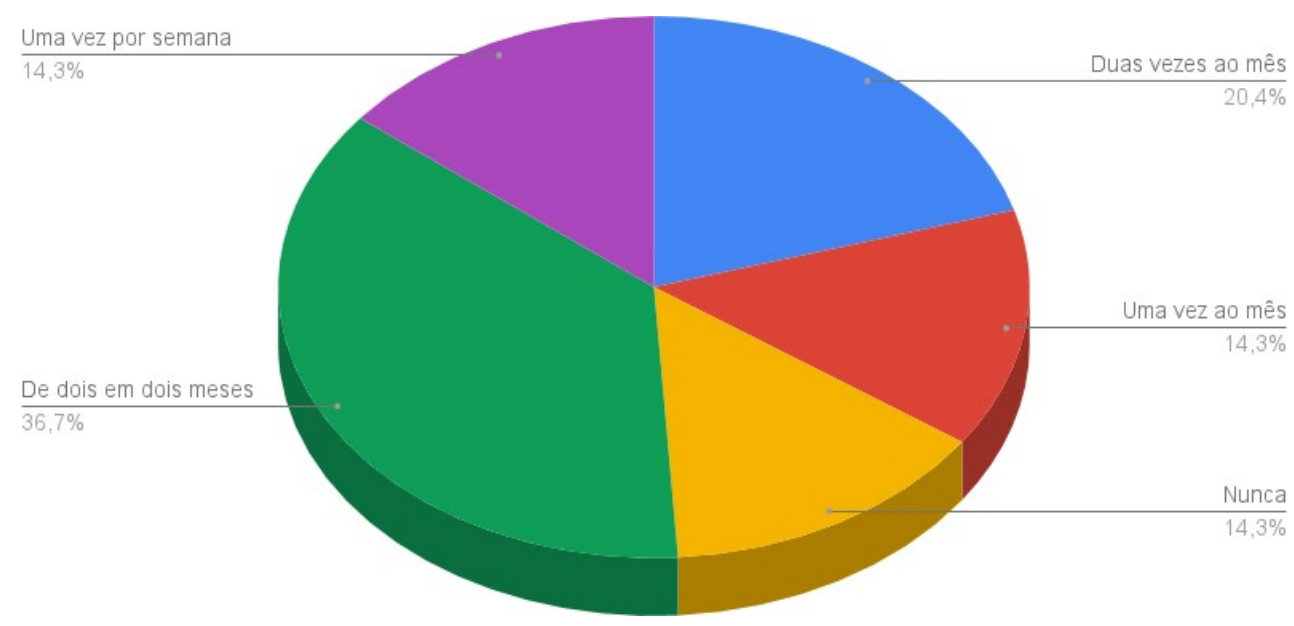

Fonte: Dados da pesquisa (2017)

O resultado aponta que uma pequena parte $(14,3 \%)$ dos pesquisados possuem uma rotina semanal de frequentar shows. Além disso, somando-se os que nunca frequentam e os que muito pouco frequentam (de dois em dois meses), obtém-se um percentual de $51 \%$, o que confirma uma falta de interesse de grande parte dos empreendedores de estar em contacto com outros agentes do mercado. Tal comportamento pode comprometer bastante a tomada de decisões num momento em que se busca compreender quais as tendências do setor, não sendo possível perceber os movimentos do mercado sem estar em contacto com ele. Uma análise SWOT, por exemplo, ficaria bastante reduzida a uma análise interna de forças e fraquezas, sem ser possível identificar forças externas, fora do controlo do artista ou oportunidades que possam beneficiar uma carreira, o que compromete bastante a capacidade de responder às questões estratégicas que se apresentam. 
pontedilitora $\quad \mathbf{e}^{3} \mid=$

Gráfico 4 - Frequência em encontros, palestras, seminários ou feiras relacionados ao mercado musical.

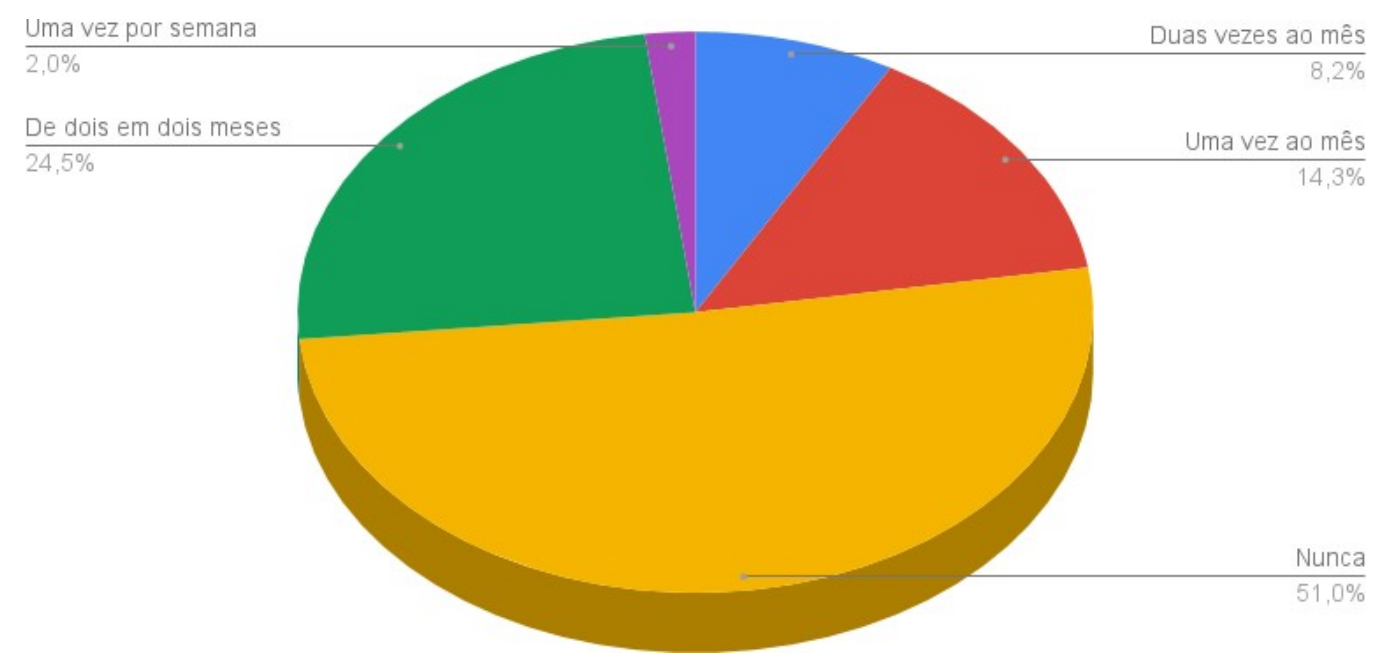

Fonte: Dados da pesquisa (2017)

Nota-se na análise do Gráfico 4 que 51,0\% dos entrevistados nunca participaram de eventos relacionados o setor musical. Na opinião de Hamel e Prahalad (1995), existe algo mais na previsão do futuro de um setor do que simples lampejos ofuscantes de insight. A previsão do futuro do setor baseia-se em perceções profundas das tendências da tecnologia, demografia, regulamentação e estilos de vida que podem ser utilizados para reescrever as regras do setor e criar um novo diferencial competitivo. Embora a compreensão das implicações potenciais dessas tendências exija criatividade e imaginação, qualquer visão que não se baseie em fundamentos factuais sólidos, possivelmente, será uma visão fantasiosa. Assim sendo, a melhor maneira de se obter uma boa visão do mercado musical consiste em relacionar-se com outras pessoas do mesmo setor. De acordo com o Gráfico 4, este não é um comportamento comum entre os entrevistados, revelando mais uma vez, a falta de uma estratégia para melhor entender o comportamento do ambiente externo.

Objetivando compreender como se dá o planeamento dos empreendimentos musicais, perguntou-se como é realizada a marcação de shows. Se ocorre por meio de 


\section{pontěditora}

um planejamento anterior ou simplesmente conforme as oportunidades se apresentem.

O Gráfico 5 apresenta os resultados.

Gráfico 5 - Planeja shows ou marca conforme oportunidade

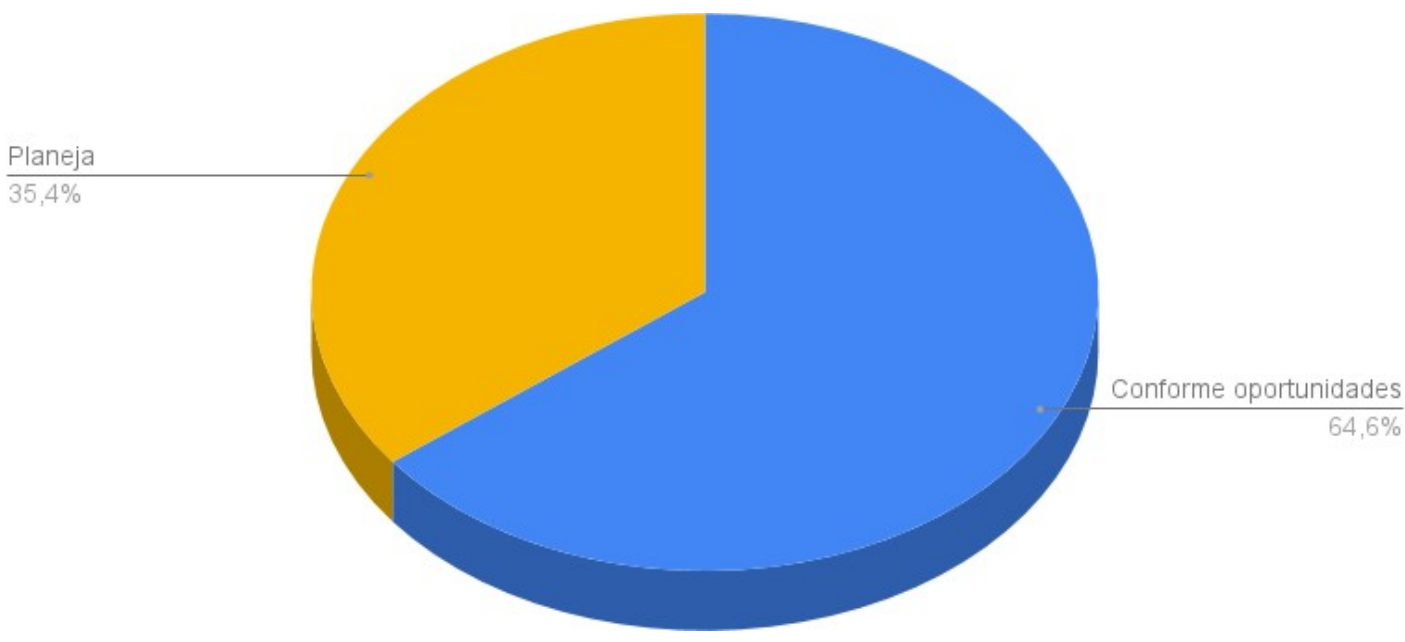

Fonte: Dados da pesquisa (2017)

A maioria dos pesquisados $(64,6 \%)$ afirmou não realizar planeamento de seus shows, agendando-os conforme surgem as oportunidades. Tal resultado demonstra, no que se refere a busca por melhores oportunidades, que a maioria dos empreendedores não adota uma visão estratégica em relação aos seus shows. Um dos eixos principais do mercado da música são as apresentações ao vivo, sendo de suma importância investir no planeamento a fim de atingir o público-alvo, definido e conseguir melhores resultados.

Esse entendimento é reforçado pelo Entrevistado X1 quando afirma que:

O principal ponto forte acredito ser a performance da banda ao vivo, não por sermos músicos fenomenais, somos bons o suficiente, mas o principal é que o público ao ver nossa apresentação consegue relacionar nosso discurso com a música. Ao definirmos muito bem nosso público alvo, planejamos nossos shows de forma a sempre nos apresentarmos para públicos que buscam nosso produto, e portanto, o retorno que conseguimos sempre é muito melhor.

$\mathrm{e}^{3}$ - Revista de Economia, Empresas e Empreendedores na CPLP | Volume 4 | Número 1 


\section{pontěditora}

O Gráfico 6 apresenta os resultados relativos à realização de reuniões com colaboradores a fim de se tratar exclusivamente do planeamento.

\section{Gráfico 6 - Realiza reuniões para tratar de planeamento}

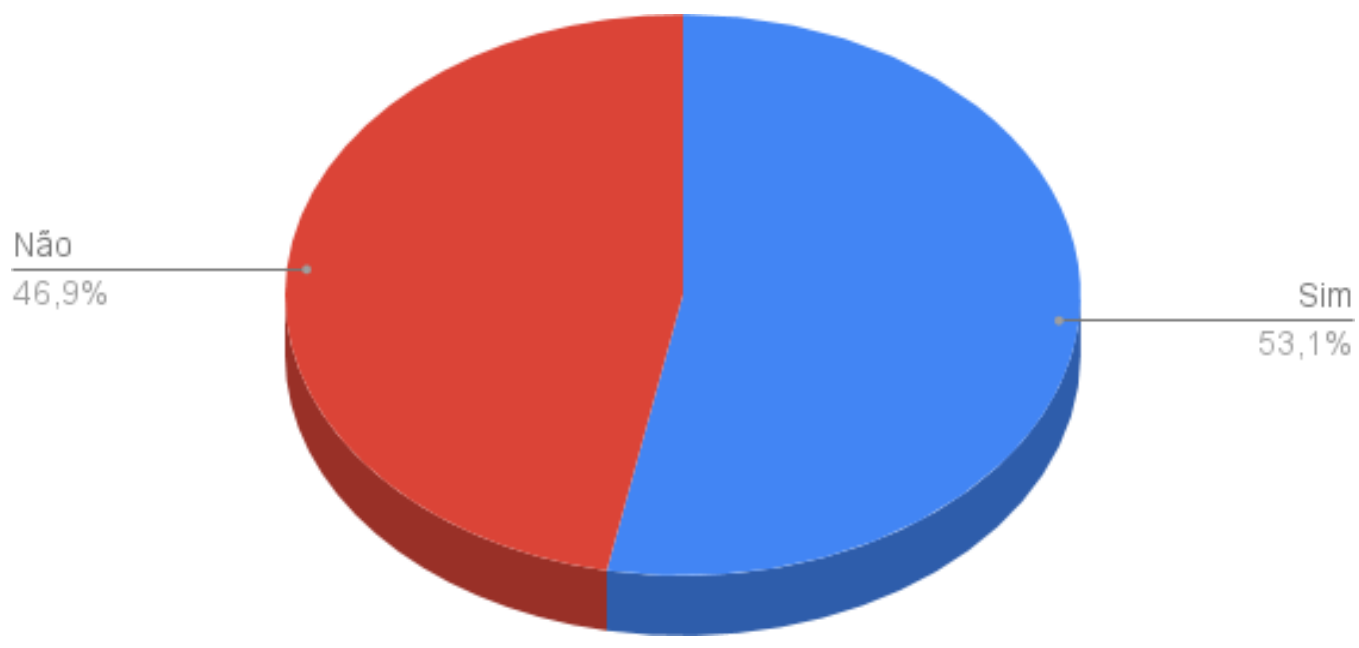

Fonte: Dados da pesquisa (2017)

O Gráfico 6 mostra que um pouco mais da metade dos entrevistados (53,1\%) realizam encontros com o objetivo de discutir ações de planeamento. Isso demonstra que ainda grande parte dos empreendedores não se preocupa com o planeamento, ficando focados somente nos aspetos artísticos e musicais do empreendimento em detrimento dos aspetos relacionados à gestão do negócio. Tal abordagem representa uma visão já ultrapassada de uma carreira artística, uma vez que hoje o empreendedor musical representa o principal motor de sua carreira.

$\mathrm{O}$ modelo de investimento também mudou. Atualmente, os lançamentos da maioria dos discos acontece por meio de pequenas gravadoras ou diretamente pelos artistas. Os grandes grupos não investem mais em promessas, preferem investir em carreiras consolidadas, com púbico formado. Isso representa mais responsabilidades para o artista, uma vez que sua gestão de carreira não pode ser mais delegada, forçando o músico a agir como um empreendedor. Para tanto, deve-se trabalhar duro. Ter visão empreendedora torna-se uma competência fundamental para o músico ser capaz de 


\section{pontěditora}

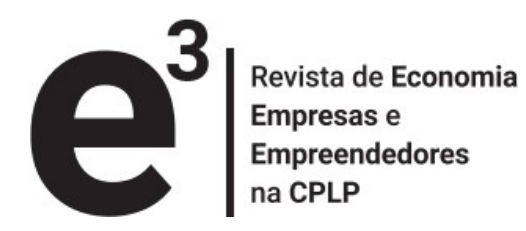

traçar estratégias adequadas. O planeamento representa o segredo para atingir bons resultados (LA OTRA, 2017).

Buscando identificar na concorrência a perceção dos mesmos no que diz respeito ao seu foco de atuação e onde pretende chegar com o negócio, perguntou-se se existe missão e visão definidas. Nota-se que um pouco menos da metade $(45,8 \%)$ dos pesquisados não possuem uma missão para o seu negócio, o que representa que não foram estabelecidas as diretrizes desse trabalho. A missão consiste na identificação da razão pela qual o trabalho existe e sua inexistência aponta um grave sinal de que grande parte dos pesquisados não possuem um propósito em suas carreiras. As carreiras sem propósito não podem sobreviver num mercado competitivo.

Em relação aos 54,2\% restantes que declaram possuir uma missão, poucos deles souberam definir adequadamente a sua razão de existir. Na sua maioria, declaram como sua missão o desejo de ser sustentável, divertir o público, entreter ou resgatar algum estilo musical. Mais uma vez, a falta de uma visão estratégica fica clara, uma vez que em nenhuma das respostas foram citados aspetos que demonstrem um claro posicionamento perante o público-alvo e o mercado, como ser referência no setor ou em determinado nicho, aspetos que demonstrem uma razão de existir mais definida e profunda.

Um bom exemplo, a fim de comparação, entre uma visão bem definida e outra nem tanto, pode ser observado por meio das entrevistas. Observem a definição de visão apontada pelo Entrevistado X2, quando afirma que, "Minha visão é proporcionar a todos os envolvidos uma interação na qual todos compartilhem a mesma emoção".

Para o Entrevistado X1, “A missão do meu empreendimento é fazer rock brasileiro pesado com identidade e competência, buscando alcançar o grande mercado da música sendo referência no meu nicho".

O Entrevistado X1 soube definir bem a sua missão, explicitando pontos fortes do seu trabalho (identidade e competência), aspetos empresariais (empreendimento), além de definir claramente a razão para tal empreendimento existir (alcançar o grande mercado da música, sendo referência no meu nicho). Já o Entrevistado X2 focou em aspetos mais pessoais e emocionais, onde define a sua razão de existir como a interação entre o seu trabalho e o público ao redor da mesma emoção. Uma missão, portanto, nem um pouco definida e não voltada para o mercado. 


\title{
pontěditora
}

Em relação à visão, mais uma vez, observou-se que os pesquisados, mesmo respondendo positivamente que possuem visão, não conseguiram apresentar previsões que se baseiem em tendências mercadológicas, o que dificulta bastante perceber para onde as coisas vão, quais são as forças que se opõem aos objetivos da organização, como lidar com elas, quais são as oportunidades que se abrem, como aproveitá-las bem. Novamente observa-se uma falta de visão estratégica dos empreendedores musicais, em sua maioria.

Observa-se, ao confrontar as respostas de ambos os entrevistados, que um deles, Entrevistado X1, possui uma visão estratégica mais bem definida, com os pontos fortes e fracos, e as ameaças e oportunidades mais de acordo com o mercado o que permite elaborar as suas ações, buscando um diferencial em relação aos seus concorrentes. Segundo o Entrevistado X1:

\begin{abstract}
Algumas ações realizadas pela banda podem ser citadas: ampliação do público-alvo com apresentações fora de Belo Horizonte, busca por recursos via Lei de Incentivo, inclusive com projetos aprovados, estruturação de uma base de fãs, busca por parcerias e foco direcionado à um nicho especifico da música. Todas ações refletem em nos resultados alcançados, mais expressivos e concretos do que o da concorrência.
\end{abstract}

É importante ressaltar que o Entrevistado X2 possui grande um talento musical, sendo um excelente instrumentista, entretanto, os seus melhores resultados não são concretos. De acordo com as suas respostas, curtas e muitas vezes muito subjetivas, a sua carreira não está em conformidade com a de empreendedor musical, atento à necessidade de se possuir uma visão estratégica do seu setor.

\section{Considerações finais}

O objetivo desta pesquisa consistiu em desenvolver um planeamento estratégico para um empreendimento musical (Lugera), a fim de se impulsionar a carreira de tal empreendimento.

A música talvez seja uma das expressões artísticas mais presentes no nosso cotidiano, contemplando toda a sociedade, sem distinção de classes sociais, local ou idade. Diferentemente do que um leigo possa imaginar, a indústria musical atual não se concentra somente no chamado mainstream ou no grande mercado, a corrente principal.

$\mathrm{e}^{3}$ - Revista de Economia, Empresas e Empreendedores na CPLP | Volume 4 | Número 1 


\section{pontěditora}

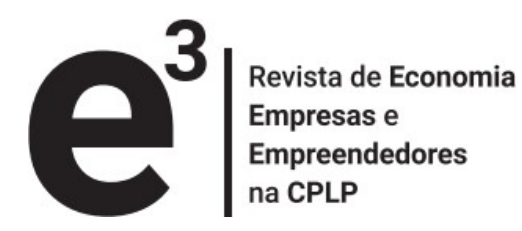

As oportunidades apresentam-se para todos, dos músicos independentes às grandes corporações ligadas às vendas digitais. Vários artistas, focados nos seus nichos de mercado, literalmente micromercados de música, obtêm um considerável sucesso nas suas carreiras, atingindo a autossuficiência nos seus empreendimentos.

A utilização de técnicas para a gestão de carreiras, marketing, construção de marcas e oferta de conteúdo, serviços e produtos que proporcionem experiências e sentimentos diferenciados para o público, pode representar um grande diferencial em trabalhos artísticos que buscam estabelecer-se como empreendimentos de sucesso.

Num mercado musical cada vez mais competitivo, profissionais não capacitados tendem a limitar as suas possibilidades de sucesso, enfraquecendo a cena musical local. Dos inúmeros projetos independentes lançados ligados à área musical, poucos conseguem conquistar, minimamente, um público disposto a apoiar as suas carreiras. Tal facto deve-se, na maioria dos casos, à falta de um planeamento estratégico por parte dos empreendedores, que muitas vezes nem sequer conseguem definir o seu públicoalvo.

Os resultados da pesquisa revelam uma grande carência de uma visão estratégica dos empreendedores musicais e, como consequência, uma redução das possibilidades de obter-se melhores resultados, sejam financeiros ou de satisfação, aos seus agentes. Portanto, um planeamento estratégico aplicado a um empreendimento musical pode ser um grande diferencial para artistas interessados em obter retornos acima da média, assim como ser um instrumento para a gestão de carreiras empreendedoras de sucesso.

Algumas limitações encontradas para a realização do trabalho foram o número de pessoas disponíveis para responder o questionário que, no caso desta pesquisa, ficou bem próximo do mínimo exigido, porém, esperava-se maior envolvimento por parte de pessoas que compõem o cenário da música independente na cidade. Além disso, grande número de respostas fugiram totalmente daquilo que era esperado, demonstrando que para muitos dos entrevistados o assunto Planeamento Estratégico é totalmente desconhecido.

Diante disso, com o objetivo de atender a proposta inicial do estudo, foi desenvolvido o plano estratégico para a banda Lugera, tendo como alvo impulsionar a carreira musical independente da banda. 


\section{pontěditora}

Como proposta, apresenta-se o planeamento estratégico a ser adotado pela Banda Lugera, apresentando uma análise do ambiente organizacional, elaboração dos princípios norteadores (valores, missão e visão) da banda, formulação dos objetivos estratégicos e elaboração de um plano de ação a ser aplicado no desenvolvimento do empreendimento musical.

\subsection{Análise do ambiente}

A primeira etapa do planeamento estratégico consiste num processo de monitoração do ambiente organizacional, também conhecido como análise SWOT. De acordo com Certo e Peter (2005), o ambiente organizacional compreende todos os factores, internos e externos, que podem influenciar o progresso alcançado por meio da realização dos objetivos.

Quadro 1 - Análise SWOT da banda Lugera

\begin{tabular}{|c|c|c|}
\hline & Positivos & Negativos \\
\hline $\begin{array}{l}\text { Factores } \\
\text { internos }\end{array}$ & $\begin{array}{l}\text { Pontos fortes: } \\
\text { - } \text { Proposta musical } \\
\text { diferenciada; } \\
\text { - Figurino; } \\
\text { - Bons músicos; } \\
\text { - Experiência no mercado; } \\
\text { - } \text { Boa rede de comunicação } \\
\text { via internet; } \\
\text { - Material de boa qualidade; } \\
\text { - Estúdio de ensaio e gravação } \\
\text { próprio; } \\
\text { - Boa relação entre os } \\
\text { - } \text { músicos; } \\
\text { - possuemobilidade (todos } \\
\text { - Produtor/agente em São } \\
\text { Paulo; } \\
\text { Todos integrantes } \\
\text { registrados em associação de } \\
\text { gestão de direito autoral; } \\
\text { - Música registradas; } \\
\text { Bons retornos das } \\
\text { plataformas de streaming; } \\
\text { Ganhos com direitos } \\
\text { autorais e royalties. }\end{array}$ & $\begin{array}{l}\text { Pontos fracos: } \\
\text { - Recursos financeiros } \\
\text { limitados; } \\
\text { - Banda com pouco tempo de } \\
\text { formação; } \\
\text { - Poucos shows realizados; } \\
\text { - Nenhuma parceria em Belo } \\
\text { Horizonte; } \\
\text { - Nenhum contacto com a } \\
\text { imprensa local; } \\
\text { - Desconhecimento da marca; } \\
\text { - Falta de distribuidora/selo; } \\
\text { - Não existem produtos para } \\
\text { venda além das músicas; } \\
\text { - Perda de parte do público } \\
\text { brasileiro devido às músicas } \\
\text { - serem em inglês; } \\
\text { Dificuldade em produzir } \\
\text { vídeos com maior frequência. }\end{array}$ \\
\hline
\end{tabular}

$\mathrm{e}^{3}$ - Revista de Economia, Empresas e Empreendedores na CPLP | Volume 4 | Número 1 


\begin{tabular}{|c|c|c|}
\hline $\begin{array}{l}\text { Factores } \\
\text { externos }\end{array}$ & $\begin{array}{l}\text { Oportunidades: } \\
\text { - } \text { Aumento da popularidade } \\
\text { das plataformas de } \\
\text { streaming com o aumento } \\
\text { das vendas digitais; } \\
\text { - Organização da cena } \\
\text { independente com cada vez } \\
\text { mais espaços para bandas } \\
\text { autorais; } \\
\text { - Oportunidades em teatros do } \\
\text { SESC e SENAI, em vários } \\
\text { estados, que geram } \\
\text { excelentes ganhos com } \\
\text { direitos autorais; } \\
\text { Licenciamento de músicas } \\
\text { para filmes e comerciais; } \\
\text { Novos editais de Lei de } \\
\text { Incentivo; } \\
\text { Aumento do número de } \\
\text { concursos para bandas } \\
\text { autorais; } \\
\text { Poucos concorrentes com } \\
\text { propostas similares. }\end{array}$ & $\begin{array}{l}\text { Ameaças: } \\
\text { - Crise económica e } \\
\text { consequente redução de gastos } \\
\text { com entretenimento e música; } \\
\text { - Mudanças em leis } \\
\text { relacionadas ao direito } \\
\text { autoral; } \\
\text { - Preconceito de certa parcela } \\
\text { do público com o segmento } \\
\text { pop/eletrónico; } \\
\text { - Aumento dos custos com } \\
\text { equipamentos e acessórios } \\
\text { relacionados a música. }\end{array}$ \\
\hline
\end{tabular}

Fonte: Elaborado pelo autor (2017)

\subsection{Estabelecimento das diretrizes organizacionais}

Nesta segunda etapa, tendo por base a entrevista com um dos integrantes da banda Lugera, sugerem-se os princípios norteadores do empreendimento (valores, missão e visão). Valores "são os balizamentos para o processo decisório e o comportamento da empresa no cumprimento da sua missão" (VASCONCELOS; PAGNONCELLI, 2001, p. 31).

Os valores da banda Lugera são:

- Autenticidade: a base para um trabalho coeso inclui liberdade criativa, coerência nas ações e espontaneidade.

- Interatividade: o convívio e a troca de experiências com outros artistas gera um dinamismo favorável à cena musical.

- Humildade: característica das pessoas que sabem assumir as suas responsabilidades, sem arrogância, prepotência ou soberba. 
- Empreendedorismo: agregar valor, saber identificar oportunidades e transformálas em um negócio lucrativo.

Missão "é a razão de existir da empresa no seu negócio" (VASCONCELOS; PAGNONCELLI, 2001, p. 31). A missão da banda Lugera é "fazer música pop que leve entretenimento de qualidade ao grande público, de maneira profissional e criativa a fim de se tornar referência no cenário pop/eletrônico nacional".

Visão "é a explicitação do que se visualiza para a empresa" (VASCONCELOS; PAGNONCELLI, 2001, p. 31). A visão da banda Lugera é "estabelecer um trabalho auto sustentável dentro do nicho específico da música pop eletrônica, conquistando o reconhecimento do público a nível nacional".

\subsection{Formulação da estratégia e plano de ação}

Nesta etapa apresentam-se os objetivos definidos a partir das análises realizadas e seus respectivos planos de ação.

1. Recursos financeiros da banda. Estabelecer um fundo abastecido por contribuições mensais no valor de cem reais para custear quaisquer despesas inerentes ao projeto. Essa proposta já poderá ser adotada de imediato.

2. Contacto com a imprensa. Realizar levantamento de todos os contactos disponíveis da área jornalística, que podem ser obtidos com consulta aos expedientes dos jornais, buscas via internet, ligações telefónicas ou até mesmo encontros presenciais. A partir do levantamento, será criado um press release que será enviado a todos os contactos. Seria interessante também que a banda contratasse um profissional de assessoria de imprensa para conseguir algumas aparições na mídia. Esse item deverá ser realizado até o final de 2017.

3. Shows. Nessa área a banda pretende atuar em duas localidades, em Belo Horizonte fomentando a cena local, e em São Paulo, por meio do produtor/agente da banda. Para Belo Horizonte a proposta será realizar um show numa casa mais conceituada no cenário autoral, por exemplo a "Autêntica", localizada na Savassi. Para tanto, deverá entrar em contacto com os produtores da casa e buscar oportunidades para o primeiro semestre de 2018. Para São 


\section{pontěditora}

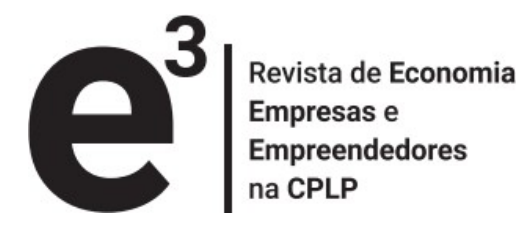

Paulo, o objetivo consiste em conseguir oportunidades em locais que ofereçam bons cachês e retornos com direitos autorais. Para tanto, o produtor/agente da banda mantém contato com o SESC, que possui várias unidades na cidade e uma agenda de shows constante. O objetivo será fazer uma série de shows na cidade a partir do segundo semestre de 2018.

4. Parceria com um selo de distribuição, de preferência internacional. Tal tarefa também será de responsabilidade do produtor/agente da banda e o prazo para a realização é até junho de 2018.

5. Parceria com algum artesão/designer para a produção de produtos exclusivos da banda. Um produto diferenciado, por exemplo, seria uma miniatura das máscaras usadas pelos músicos nas suas apresentações, que poderiam ser vendidas como pingentes, brincos, esculturas, enfim, uma série de produtos que seriam diferenciados pelo design. Além disso, seriam implementadas lojas virtuais nas páginas da banda e na fã page no Facebook. O objetivo será de até junho de 2018 estar com tudo funcionando e oferecer um mix de pelo menos 5 produtos.

6. Lançar um single e um videoclipe até o final do ano. Tal tarefa encontra-se em realização, a música já foi gravada, o cinegrafista já está acertado, falta, no momento, definir a locação e a data das filmagens e realizar a adição do material. Prazo até o início de 2018.

O Quadro 2, a seguir, apresenta o plano de ação elaborado para a banda Lugera, especificando a necessidade de atuação (ações), justificativas, responsáveis, prioridades, área de atuação, atividades necessárias para implantação e custos. 


\section{pontěditora}

Quadro 2 - Plano de ação

\begin{tabular}{|c|c|c|c|c|c|c|}
\hline O quê? & Para quê? & Quem? & Quando? & Onde? & Como? & Quanto \\
\hline $\begin{array}{l}\text { Necessidade } \\
\text { de atuação } \\
\text { (Ação) }\end{array}$ & $\begin{array}{l}\text { Justificativa / } \\
\text { benefícios }\end{array}$ & Responsável & $\begin{array}{l}\text { Prioridad } \\
\mathrm{e}\end{array}$ & Qual área & $\begin{array}{l}\text { Atividades necessárias } \mathrm{p} / \\
\text { implementar }\end{array}$ & $\begin{array}{l}\text { Recursos } \\
\text { financeiros } \\
\text { necessários }\end{array}$ \\
\hline $\begin{array}{l}\text { Fundo de } \\
\text { reserva }\end{array}$ & $\begin{array}{l}\text { Despesas } \\
\text { futuras }\end{array}$ & Lucas & $30 / 09 / 17$ & Banco & $\begin{array}{l}\text { Depósitos mensais de } \\
\mathrm{R} \$ 100,00 \text { para cada membro } \\
\text { da banda }\end{array}$ & $\mathrm{R} \$ 100,00$ \\
\hline $\begin{array}{l}\text { Contacto com } \\
\text { imprensa }\end{array}$ & $\begin{array}{l}\text { Divulgação do } \\
\text { trabalho }\end{array}$ & Geraldo & $30 / 12 / 17$ & $\begin{array}{l}\text { Belo } \\
\text { Horizonte }\end{array}$ & $\begin{array}{l}\text { Consulta aos expedientes dos } \\
\text { jornais, buscas via internet, } \\
\text { ligações telefónicas ou até } \\
\text { mesmo encontros presenciais. }\end{array}$ & - \\
\hline $\begin{array}{l}\text { Formulação } \\
\text { de Press } \\
\text { Release }\end{array}$ & $\begin{array}{l}\text { Divulgação do } \\
\text { trabalho }\end{array}$ & Lucas & $30 / 12 / 17$ & $\begin{array}{l}\text { Belo } \\
\text { Horizonte }\end{array}$ & $\begin{array}{l}\text { Elaborando um texto sobre a } \\
\text { banda e escolhendo fotos para } \\
\text { divulgação. }\end{array}$ & - \\
\hline $\begin{array}{l}\text { Contratação } \\
\text { de assessor de } \\
\text { imprensa }\end{array}$ & $\begin{array}{l}\text { Divulgação do } \\
\text { trabalho }\end{array}$ & Geraldo & $30 / 12 / 17$ & $\begin{array}{l}\text { Belo } \\
\text { Horizonte }\end{array}$ & $\begin{array}{l}\text { Procurando um profissional } \\
\text { através de contactos. }\end{array}$ & $\mathrm{R} \$ 3.000,00$ \\
\hline Shows BH & $\begin{array}{l}\text { Divulgação do } \\
\text { trabalho, } \\
\text { conquistar } \\
\text { mais público }\end{array}$ & Lucas & $30 / 02 / 18$ & $\begin{array}{l}\text { Belo } \\
\text { Horizonte }\end{array}$ & $\begin{array}{l}\text { Através de contacto com } \\
\text { produtores de casas de shows } \\
\text { de Belo Horizonte. }\end{array}$ & - \\
\hline Shows SP & $\begin{array}{l}\text { Divulgação do } \\
\text { trabalho, } \\
\text { conquistar } \\
\text { mais público }\end{array}$ & Ricardo & $30 / 04 / 18$ & ، & $\begin{array}{l}\text { Através de contacto com } \\
\text { produtores de casas de shows } \\
\text { e espaços culturais de São } \\
\text { Paulo. }\end{array}$ & - \\
\hline $\begin{array}{l}\text { Selo de } \\
\text { distribuição }\end{array}$ & $\begin{array}{l}\text { Divulgação do } \\
\text { trabalho, } \\
\text { conquistar } \\
\text { mais público, } \\
\text { realizar mais } \\
\text { vendas de } \\
\text { fonogramas }\end{array}$ & Ricardo & $30 / 04 / 18$ & São Paulo & $\begin{array}{l}\text { Através do produtor/agente } \\
\text { que possui contatos com selos. }\end{array}$ & $\mathrm{R} \$ 400,00$ \\
\hline
\end{tabular}




\section{pontěditora}

\begin{tabular}{|l|l|l|l|l|l|l|}
\hline $\begin{array}{l}\text { Produtos } \\
\text { exclusivos/ } \\
\text { loja virtual }\end{array}$ & $\begin{array}{l}\text { Obter renda } \\
\text { com produtos } \\
\text { exclusivos, } \\
\text { fidelizar o } \\
\text { público }\end{array}$ & $\begin{array}{l}\text { Geraldo/ } \\
\text { Lucas }\end{array}$ & $30 / 05 / 18$ & $\begin{array}{l}\text { Belo } \\
\text { Horizonte }\end{array}$ & $\begin{array}{l}\text { Através de parcerias com } \\
\text { artesãos, designers e estilistas }\end{array}$ & R \$400,00 \\
\hline $\begin{array}{l}\text { Single/ } \\
\text { videoclipe }\end{array}$ & $\begin{array}{l}\text { Divulgar o } \\
\text { trabalho, } \\
\text { atingir um } \\
\text { público } \\
\text { amplo, } \\
\text { produzir } \\
\text { conteúdo, } \\
\text { movimentar as } \\
\text { redes sociais }\end{array}$ & $\begin{array}{l}\text { Geraldo/ } \\
\text { Lucas/ } \\
\text { Roger }\end{array}$ & $01 / 06 / 18$ & $\begin{array}{l}\text { Belo } \\
\text { Horizonte }\end{array}$ & $\begin{array}{l}\text { Gravação de imagens em local } \\
\text { ainda a definir }\end{array}$ & R $\$ 200,00$ \\
\hline
\end{tabular}

Fonte: Elaborado pelo autor (2017) 


\section{pontěditora}

\section{REFERÊNCIAS}

BARON, Robert A.; SHANE, Scott A. Empreendedorismo: uma visão do processo. São Paulo: Thomson Learning, 2007.

CERTO, Samuel C.; PETER, J. P. Administração estratégica. 2. ed. São Paulo: Pearson Education do Brasil, 2005.

CHIAVENATO, Idalberto. Introdução à teoria geral da administração: uma visão abrangente da moderna administração das organizações. 7. ed. Rio de Janeiro: Elsevier, 2003.

CHIAVENATO, Idalberto; MATOS, Francisco Gomes. Visão e ação estratégica: os caminhos da competitividade. 3. ed. Barueri: Manole, 2009.

DOLABELA, Fernando. O segredo de Luísa: uma ideia, uma paixão e um plano de negócios: como nasce o empreendedor e se cria uma empresa. São Paulo: Cultura, 1999.

DORNELAS, José Carlos A. Empreendedorismo: transformando ideias em negócios. Rio de Janeiro: Campus, 2012.

GIL, Antônio Carlos. Como elaborar projetos de pesquisa. 4. ed. São Paulo: Atlas, 2008.

HAMEL, Gary; PRAHALAD, C. K. Competindo para o futuro. 18. ed. Rio de Janeiro: Elsevier, 1995.

HITT, Michael A.; IRELAND, R. Duane; HOSKISSON, Robert E. Administração Estratégica. 2. ed. São Paulo: Cengage Learning, 2008.

IFPI. FEDERAÇÃO INTERNACIONAL DA INDÚSTRIA FONOGRÁFICA. Global music report. 2016. Disponível em: $<$ http://www.ifpi.org/news/IFPI-GLOBALMUSIC-REPORT-2016/>. Acesso em: 29 abr. 2017.

KOTLER, Philip. ARMSTRONG, Gary. Princípios do Marketing. $9^{\circ}$ Edição. São Paulo: Pearson Prentice Hall, 1998.

KOTLER, Philip. KELLER, Kevin Lane. Administração de marketing. 12. ed. São Paulo: Pearson Prentice Hall, 2006.

KUSEK'S, Dave. Music Business Strategies. Cowboys Ventures, 2014. Disponível em: <http://newartistmodel.com/music-business-strategies/>. Acesso em: 04 maio 2017.

KUSEK, David; LEONHARD, Gerd. The future of music: manifesto for the digital music revolution. Boston: Berklee Press, 2005. 


\section{pontěditora}

LA OTRA. Sua carreira em suas mãos: como se adaptar ao novo cenário musical. 2017. Disponível em: <http://agencialaotra.com/2017/2017/05/02/sua-carreira-em-suasmaos-como-se-adaptar-ao-novo-cenario-musical/>. Acesso em: 03 maio 2017.

LEVESQUE, Paul. Planejar para o sucesso. São Carlos: Futura, 1999.

MARCONI, Marina de Andrade; LAKATOS, Eva Maria. Fundamentos de metodologia científica. 8. ed. São Paulo: Atlas, 2017.

MINTZBERG, Henry et al. O processo da estratégia: conceitos, contextos e casos selecionados. 4. ed. Porto Alegre: Bookman, 2006.

ROCHA, Águida Garreth Ferraz. Planejamento e gestão estratégica. São Paulo: Pearson Education do Brasil, 2012.

SALAZAR, Leonardo. Música LTDA.: o negócio da música para empreendedores. 2. ed. Recife: Sebrae, 2015.

SEBRAE. SERVIÇO BRASILEIRO DE APOIO ÀS MICRO E PEQUENAS EMPRESAS. Como montar e gerir uma empresa. 2017. Disponível em:

$<$ http://www.sebrae.com.br/sites/PortalSebrae/tipoconteudo/empreendedorismo?codTe $\mathrm{ma}=2>$. Acesso em: 25 jul. 2017.

VASCONCELOS, Paulo de; PAGNONCELLI, Dernizo. Construindo estratégias para vencer: um método prático objetivo e testado para o sucesso da sua empresa. Rio de Janeiro: Elsevier, 2001.

VERGARA Sylvia Constant. Projetos e relatórios de pesquisa de administração. 3 . ed. São Paulo: Atlas, 2007.

VICENTE, Eduardo. Da vitrola ao Ipod: uma história da indústria fonográfica no Brasil. São Paulo: Alameda, 2014.

\section{(cc)) EY-NG-SA}

O trabalho e $^{3}$ - Revista de Economia, Empresas e Empreendedores na CPLP está licenciado com uma Licença Creative Commons - Atribuição-NãoComercial-Compartilha Igual 4.0 Internacional. 